\author{
В. В. Петров, А. А. Крючин, Б. О. Березін, \\ Є. В. Беляк, О.В. Шиховець \\ Інститут проблем реєстрації інформації НАН України \\ вул. М. Шпака, 2, 03113 Київ, Україна
}

\title{
Прогнозування строків зберігання даних на оптичних Аисках
}

Наведено результати аналізу використання методів прискореного визначення строків гарантованого зберігання інформачії на оптичних носіях. Особливу увагу приділено проведенню випробувань носіїв, що призначені для довготермінового зберігання інформачії. Визначено головні причини значної різниці у строках зберігання даних на компактдисках під час проведення прискорених випробувань.

Ключові слова: оптичні носії, прискорені випробування, довготермінове зберігання інформації.

\section{Вступ}

Зростання обсягу інформації, представленої в цифровій формі, призводить до того, що питання про способи зберігання інформації на цифрових носіях стає все більш важливим. Якщо раніше вважалося за потрібне і була можливість забезпечувати довготермінове зберігання лише тих документів, значущість яких була нам зрозуміла спочатку, то тепер існує можливість перейти до архівного зберігання набагато більш широкого спектра контенту, цінність якого заздалегідь не відома, але який все ж може стати в нагоді в майбутньому. Це відображає якісний перелам у розумінні як конкретними підприємствами, так і суспільством у цілому, важливості та цінності інформаційних ресурсів, а з іншого боку - зростання технічних можливостей зі зберігання величезних обсягів інформації [1-4]. Сьогодні створюється така кількість інформації, яку майже не можливо роздрукувати на папері. Збереження даних у цифровій формі піднімає проблеми принципово іншої природи, які додаються до проблем збереження традиційних документальних матеріалів. Одна з проблем полягає в тому, що носії інформації для зберігання документів у цифровій формі мають менший термін зберігання даних навіть в ідеальних умовах, такі носії вразливі до катастрофічних утрат записаної інформації. Загрози втрати інформації, яка зберігається на сучасних цифрових носіях, якісно відрізняються від проблем зберігання даних на традиційних носіях. Якість цифрових носіїв за певних умов може швидко погіршуватися, що робить терміни рішень 
і дій щодо запобігання втратам питанням років, а не десятиліть. Поліпшення стабільності характеристик, ємності, довговічності цифрових носіїв дозволить різко знизити вразливість цифрових матеріалів до впливу зовнішніх факторів і знизити витрати на зберігання даних [1]. Недовіра до можливостей цифрових носіїв забезпечувати високу надійність довготермінового зберігання даних у цифровому вигляді призводить до того, що у багатьох випадках не змінено законодавство, яке передбачає необхідність паралельно з цифровими носіями зберігати в архівах паперові документи, в тому числі й описи документів. Використання цифрових копій документів в архівах, у першу чергу, обумовлено необхідністю вирішення питання виконання пошукових запитів [5]. Не менш складною, ніж погіршення характеристик носіїв архівного зберігання даних, $є$ проблема морального та технічного старіння систем відтворення інформації. Пристрої та програмне забезпечення для запису і зберігання інформації, замінюються регулярно новими продуктами і технологіями. Деякі експерти стверджують, що сучасні носії архівного зберігання переживуть програмне забезпечення та пристрої, необхідні для отримання записаної інформації [1]. Частково ця проблема вирішується за рахунок зворотної сумісності носіїв інформації та створення носіїв, інформація з яких може відтворюватися різними фізичними методами $[4,6,7]$.

Визначення термінів гарантованого зберігання даних на носіях архівного зберігання представляє важливу задачу, від вирішення якої залежить успішне використання носіїв у системах архівного зберігання інформації. Під час використання інформації на цифрових носіях може траплятися часткова або повна втрата даних. Причини втрати даних включають помилки персоналу, програмні або апаратні збої, фізичний знос носія, механічні пошкодження, пошкодження від впливу електромагнітних полів або підвищеної температури, через старіння і відсутність апаратного і програмного забезпечення для відтворення даних. Ці різнорідні причини вимагають різних рішень для усунення ризику їхнього виникнення $[4,8]$. На носіях довготермінового зберігання даних необхідно забезпечувати контроль цілісності збереженої інформації, особливо це стосується носіїв з функціями запису даних [9]. Необхідно знати, як довго і з яким ступенем надійності можна використати записану інформацію, грунтуючись на об'єктивних даних про гарантійні терміни зберігання різних носіїв. Для розуміння причин і механізмів погіршення якості дисків і запобігання втрати інформації доцільно розглянути питання про прогнозований термін роботи оптичних дисків, фактори, що чинять вплив на строки зберігання даних на них [8].

\section{Анаміз досвіАу використання оптичних Аисків Амя Аовготермінового зберігання Ааних}

Уже більше 30-ти років оптичні диски використовуються в архівах для довготермінового зберігання критично важливої науково-технічної інформації, патентної та конструкторської документації, медичних та юридичних документів, рентгенівських знімків тощо. Досить успішне використання оптичних дисків для довготермінового зберігання даних базується на можливостях та особливостях оптичного запису. Оптичні носії для довготермінового зберігання даних мають значні переваги порівняно з іншими технологіями зберігання даних, а саме: 
1) запис інформації на оптичні диски здійснюється безконтактно, що запобігає пошкодженню поверхні носія;

2) записані дані можуть відтворюватися різними фізичними методами;

3) для виготовлення оптичних носіїв можуть використовуватися високостабільні матеріали, перетворення в яких відбуваються при температурах понад $2000{ }^{\circ} \mathrm{C}$;

4) для відтворення даних з оптичних дисків не потрібне спеціальне програмне забезпечення;

5) запис даних на оптичні диски здійснюється у форматах, які забезпечують сумісність записаних дисків різних типів;

6) пристрої відтворення даних з оптичних дисків створені із забезпеченням зворотної сумісності. Зворотна сумісність реалізована від дисків у форматі CD до $\mathrm{BD}$;

7) характеристики оптичних дисків створюють можливості для забезпечення високої надійності довготривалого зберігання даних при змінах у широкому діапазоні температур і вологості.

Зараз головною областю застосування оптичних дисків стає архівне зберігання даних. Запропонований компаніями Sony i Panasonic у 2013 році новий формат оптичного диска високої ємності (300 Гбайт) отримав назву архівний диск. Він призначений для професійного використання оптичних дисків у системах архівного зберігання даних [10]. Нові розробки у сфері оптичних дисків для довготермінового зберігання даних відкривають нові можливості для кращого задоволення мінливих вимог систем архівного зберігання даних за строками зберігання, ємністю носіїв і швидкістю передачі даних [10-15].

3 метою визначення типів оптичних дисків та умов, за яких забезпечується тривалий час зберігання записаної інформації, у Бібліотеці Конгресу США був проведений аналіз характеристик оптичних дисків після тривалого використання та зберігання [16-18]. Результати свідчать, що диски CD-R, в яких використовуються органічні барвники, мають менший строк зберігання даних порівняно зі штампованими дисками CD-ROM. DVD-носії за рахунок більш високої щільності запису даних мають більшу ймовірність втрати записаної інформації ніж компактдиски формату CD. Суттєвий вплив на строки зберігання мають умови використання та зберігання, навіть написи на маркованому боці компакт-диску призводять до прискорення деградації носія. Було встановлено, що трапляються випадки, коли частина дисків, які були виготовлені в один період і зберігалися в однакових умовах, була повністю зруйнована, а інші носії взагалі не мали ніяких пошкоджень $[17,18]$. Результати досліджень американського Національного інституту стандартів і технологій (NIST) збігаються з результатами досліджень Бібліотеки Конгресу CША, а саме, DVD-диски зберігають дані не менше п'ятнадцяти років, а диски CD-R мають приблизно вдвічі більшу тривалість життя (рис. 1) [17].

У роботі [19] було проведено тестування показників помилок BLER (C1) бiля 70-ти носіїв формату CD-R та PI Sum 8 для більше 30-ти носіїв формату DVD+R з комп'ютерного архіву геологічного фонду України. Близькість двох нижніх графіків на рис. 2 показує незначну різницю показників помилок у більш нових CD-R, записаних у 2005-2012 pp., та CD-R, записаних раніше, у 2002-2005 pp. 
Крім того, більша частина графіків розміщена нижче значення 100 показника помилок, тобто попадає у градацію задовільної якості. Два верхніх графіки (рис. 2) розраховані за допомогою даних про зберігання колекції CD-дисків у Бібліотеці Конгресу США [16] (тестування дисків колекції проводилося з періодом у шість років).

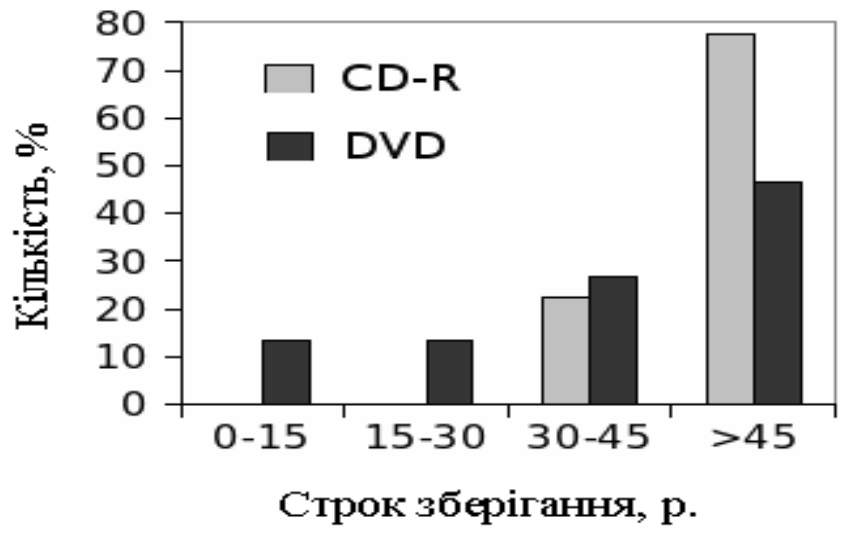

Рис. 1. Строки зберігання даних на компакт-дисках різних типів

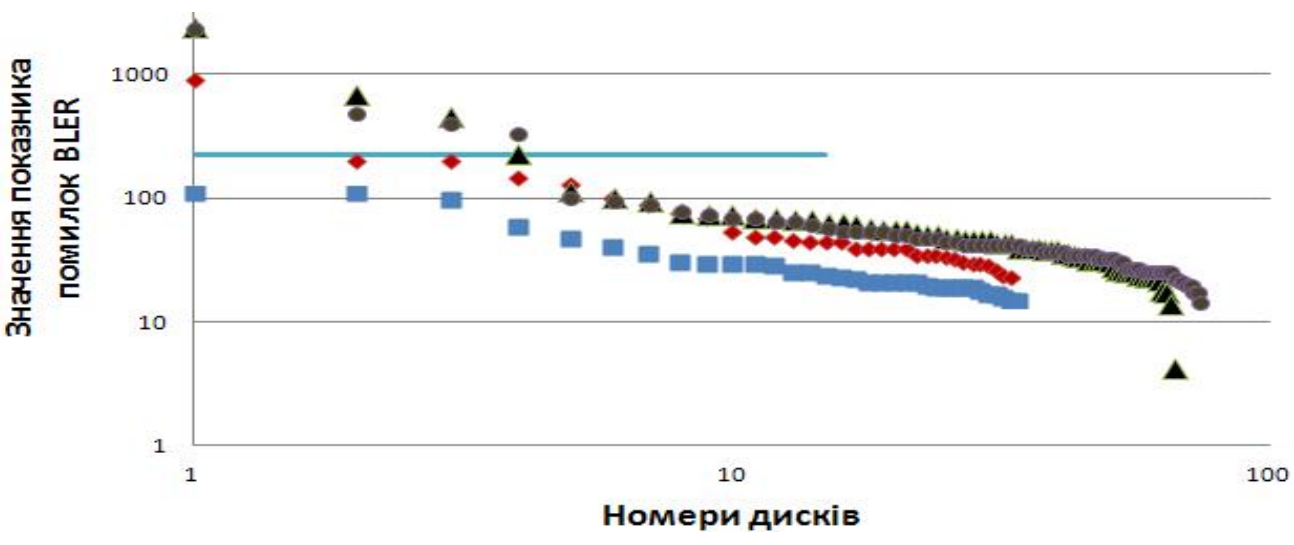

Рис. 2. Розподіл CD-R дисків, ранжируваних за кількістю помилок BLER

На рис. 2 осі представлені в логарифмічному масштабі. Тому близькій до прямої лінії характер розподілів показує можливість їхньої апроксимації степеневою функцією. Графіки, отримані в [19] на основі тестування показників помилок PI Sum 8 для DVD+R дисків, записаних у період 2014 р. та в період з 2008 р. до 2013 р. теж розміщуються достатньо близько один від одного, тобто різниця між рівнем помилок незначна, та основна кількість дисків 3 інформацією має рівень показника помилок менше 100.

Дослідження терміну зберігання носіїв CD-ROM показали, що він змінюється у широкому діапазоні від 20-ти до 12000 років з середнім терміном зберігання 1592 роки [20]. На строк зберігання даних на диску CD-ROM сильно впливають характеристики металевого відбивального шару. В усіх типах компакт-дисків використовується захист металевого шару спеціальними плівками від фізичного 
зносу, а також від окислення або забруднення. Наявність проколів у металевому шарі зменшує час зберігання даних. Окислення металевого шару компакт-диска 3 плином часу може бути виміряне в процесі прискорених випробувань компактдисків на старіння [21]. Дослідження, що проведені у Бібліотеці Конгресу США, показали, що CD-ROM, вироблені з дотриманням усіх технічних вимог, повинні зберігати дані кілька десятиліть [22]. Досягнення тривалих строків зберігання даних на носіях типу ROM можливо при суворому дотриманні технологічних умов виготовлення носіїв та обмеженому їхньому використанні в період зберігання. Багаторазові відтворення можуть навіть призводити до зміни розмірів пітів у інформаційному шарі компакт-диска. Необхідно також відзначити високу вартість виготовлення малих серій таких носіїв порівняно з оптичними носіями, на які може здійснюватися запис даних (CD, DVD, BD-R) [23]. Тривалість життя оптичних дисків з можливістю запису даних залежить від багатьох факторів, включаючи властивості використаних матеріалів при виробництві дисків, умови та режими запису й умови зберігання. Найбільш сильно строки зберігання залежать від використаних барвників у носіях з одноразовим записом. На строки зберігання оптичних носіїв суттєвий вплив мають геометричні розміри та форма направних доріжок на підкладках компакт-дисків $[24,25]$. У результаті, термін служби записаного диска надзвичайно важко надійно оцінити. Тим не менш, для розрахунку строку життя диска проводять прискорені випробування. Взагалі кажучи, розглядається тільки вплив підвищеної температури та вологості. Ці результати випробувань потім використовуються для прогнозування, як довго диск залишатиметься працездатним при нормальних умовах зберігання. Історично, виробники стверджують, що для дисків CD-R строк життя становить від 50-ти до 200-от років і 20-100 років для CD-RW [26]. Мікроструктурний аналіз записаних відбитків і хімічний аналіз відбивального шару після прискорених випробувань показав, що спостерігається поступова фізична деформація записаних країв відбитків і хімічна зміна складу відбивального шару, які можуть суттєво впливати на рівень помилок при відтворенні даних [27]. Для підвищення надійності зберігання даних на компакт-дисках DVD-R пропонується використовувати двошаровий відбивальний шар срібло-золото (так звана технологія Archival Grade Gold DVD-R) [28]. Зміна характеристик оптичних дисків, на яких робиться запис інформації або здійснюється перезапис даних, та виникнення дефектів на них, у першу чергу пов'язані 3 деградацією фоточутливого шару. Оптичні носії, на яких записана інформація представлена у вигляді мікрорельєфних структур, мають потенційно більш високу надійність зберігання інформації завдяки можливості виготовлення підкладки носія з високостабільних матеріалів і відтворення записаної інформації різними (і не тільки оптичними) методами. Підвищення надійності зберігання даних на оптичних дисках DVD-R, BD-R пов'язують з використанням більш фоточутливих матеріалів. Результати проведених чисельних досліджень показали, що суттєвий вплив на строки та надійність зберігання даних мають властивості світловідбиваючого шару, який використовується в усіх типах компакт-дисків. Використання термочутливого шару з високим коефіцієнтом відбиття дозволило не використовувати у М-дисках світловідбиваючі шари, що стало однією зі складових значного підвищення гарантованого строку зберігання даних [29]. 
Компакт-диски зберігають записану інформацію в цілому довше, ніж інші цифрові носії інформації. Досвід тривалого використання компакт-дисків довів, що їхнє використання є розумним вибором для архівації даних, тексту і зображень у цифровому вигляді. Дослідження 3 довготермінового зберігання даних на компакт-дисках показали, що нікелеві матриці, які використовуються для тиражування компакт-дисків, можуть забезпечити довготермінове зберігання даних $[6,21]$.

\section{Техномогії прискорених випробувань оптичних дисків}

Оцінка строків життя оптичних носіїв найчастіше виконується з використанням прискорених випробувань при підвищених температурі та вологості, що засновані на методах Арреніуса та Ейрінга. В процесі випробувань контролюється кількість помилок при відтворенні даних з оптичних носіїв. На рис. 3 наведено типову зміну кількості помилок у процесі прискорених випробувань носіїв DVD-R [27].

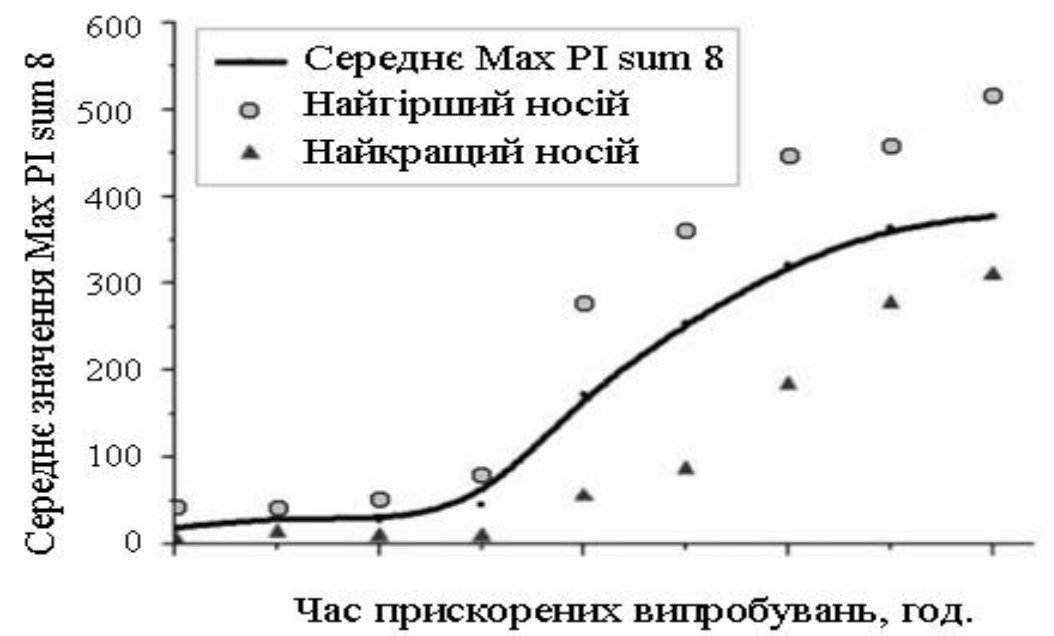

Рис. 3. Типова зміна кількості помилок у процесі прискорених випробувань носіїв DVD-R [27]

При випробуваннях оптичних носіїв використовуються такі нормативні документи [30]:

- ISO Standard 18921:2008 «Imaging materials - Compact discs (CD-ROM) - Method for estimating the life expectancy based on the effects of temperature and relative humidity». Стандарт ISO 18921:2008 «Реєструвальні матеріали — компактдиски (CD-ROM) - метод оцінки очікуваної тривалості життя, заснований на впливі температури і відносної вологості». (Для CD-ROM дисків);

— ISO Standard 18927:2008 «Imaging materials - Recordable compact disc systems - Method for estimating the life expectancy based on the effects of temperature and relative humidity». Стандарт ISO 18927:2008 «Реєструвальні матеріали - компакт-диски, що записуються - метод оцінки очікуваної тривалості життя, заснований на впливі температури і відносної вологості». (Для CD-R дисків); 
- Standard ECMA-379 (equivalent to ISO/IEC 10995:2008) «Test Method for the Estimation of the Archival Lifetime of Optical Media». Стандарт ECMA -379 (еквівалент ICO/МЕК 10995:2008) «Метод випробування для оцінки часу архівного зберігання оптичних носіїв». (Для DVD-R/RW, +R/+RW дисків);

— Standard ISO/IEC 16963:2015 Information technology — Digitally recorded media for information interchange and storage - Test method for the estimation of lifetime of optical disks for long-term data storage. Стандарт ISO/IEC 16963:2015 Iнформаційні технології - Цифрові носії для обміну та зберігання інформації Метод випробування для оцінки терміну служби оптичних дисків для довготермінового зберігання даних. (Для DVD-R/RW/RAM дисків, $+\mathrm{R} /+\mathrm{RW}$ дисків, CD$\mathrm{R} / \mathrm{RW}$ дисків і дисків BD із записом/перезаписом);

- Tests conducted by the National Institute of Standards and Technology in the USA as part of the «Optical Media Longevity Study» (Випробування, проведені в Національному Інституті стандартів і технологій США в рамках «дослідження довголіття оптичних носіїв»);

- Tests conducted by CDs21 Solutions and the Archive Disc Test Center in Japan (Випробування, проведені за програмою CDs21 у випробувальному центрі архівних дисків Японії).

Прискорене старіння використовується для визначення середньої тривалості життя інформації, що зберігається на оптичних дисках. У процесі прискореного старіння зразки піддаються впливу більш жорстких умов, ніж умови навколишнього середовища, при яких вони зазвичай зберігаються. Метою таких досліджень $\epsilon$ визначення інтенсивності відмов при декількох температурах і рівнях вологості для встановлення кількісної залежності швидкості відмов носіїв від цих параметрів. Після встановлення такого зв'язку, термін служби оптичних дисків може бути математично екстрапольований на нормальні умови зберігання. Визначаючи швидкість, з якою зміни відбуваються, можливо передбачити, коли диски повинні бути переписані для того, щоб інформація не втратилась. Вплив температури і відносної вологості на рівень помилок може бути змодельований за допомогою модифікованих рівнянь Ейрінга або Арреніуса [20, 23, 27, 30-34]. Для дисків CD, CD-R та CD-RW вимірюється показник Block Error Rate (BLER) - кількість блоків даних із помилками, які можуть бути виправлені декодером першого рівня), його допустиме значення 220 помилок на секунду. Для дисків DVD-R/RW, $+\mathrm{R} /+\mathrm{RW}$ кількість помилок вимірюється максимальним значенням показника PI Sum 8. Значення PIE (Parity Inner Error ) — це кількість рядків парності блоку ЕСC 3 помилками (Error Correction Code - код корегування помилок), а PI Sum 8 значення для 8-ми послідовних ЕСС з блоку. Максимальне допустиме значення РI Sum 8 складає 280 помилок на секунду. Значення PI Sum 8 більше ніж 280 означає неможливість використання носія інформації [36].

Вплив зовнішніх факторів на різні типи оптичних носіїв інформації призводить до різних наслідків залежно від стабільності використаних матеріалів, умов запису, відносної чутливості записуючого шару до впливу тепла, вологості та світла. На довговічність носія впливає ще низка факторів, а саме: якість виробничого процесу; тип маркування носія; сумісність носія з пристроєм запису; вік носія на час запису; умови зберігання і кількість звернень під час використання. Вплив цих численних факторів робить прогнози фактичного строку, або навіть середньої 
тривалості життя край складними. Тестування шляхом штучного старіння дозволяє отримати лише приблизну оцінку фактичного довголіття носія [23, 31, 35]. Наведені на рис. 4 дані про збільшення кількості помилок після проведення випробувань дисків DVD-R свідчать про залежність строків зберігання від умов виготовлення носіїв [7].

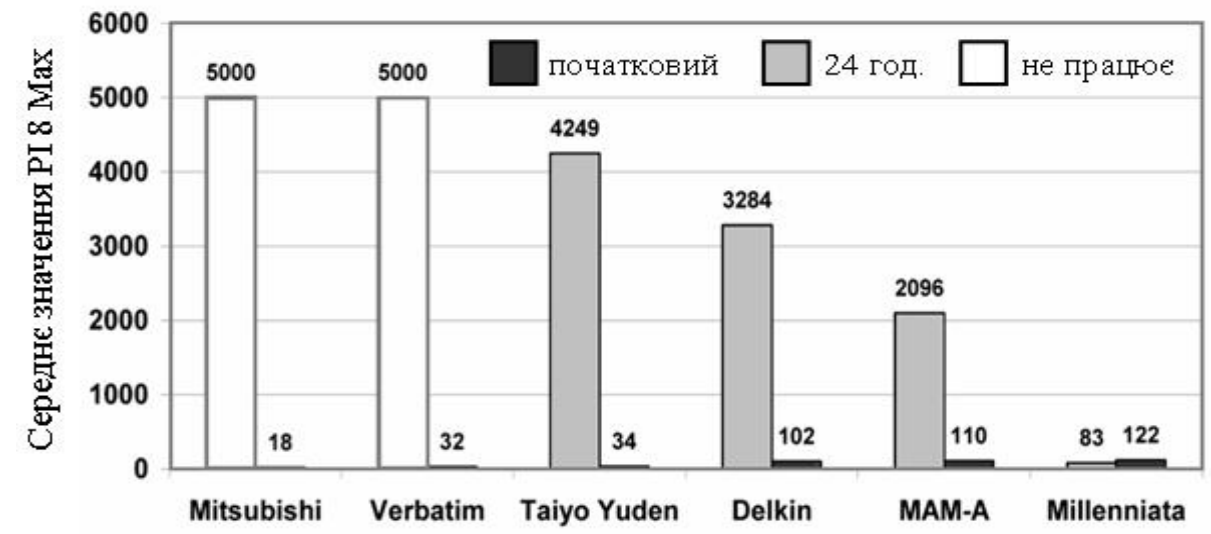

Рис. 4. Дані про збільшення кількості помилок після проведення випробувань дисків DVD-R різних виробників [7]

Для прогнозування строків зберігання оптичних дисків за стандартом ISO 18927:2013 використовують модель Арреніуса на основі аналізу збільшення кількості помилок в оптичних дисках в умовах підвищеної температури і вологості. Метод випробувань з використанням даної моделі передбачає виконання наступної послідовності операцій.

1. Дані записуються на оптичний носій та вимірюється кількість помилок.

2. Носій витримують при трьох значеннях температури: $90{ }^{\circ} \mathrm{C}, 80{ }^{\circ} \mathrm{C}, 70{ }^{\circ} \mathrm{C}$ та відносній вологості 85 \% протягом тривалого періоду часу (починаючи від 4120 годин до 5711 годин). Випробування можуть також проводитися при значеннях вологості $85 \%$

3. Періодично контролюється рівень помилок.

4. Строк зберігання при певній температурі визначається при перевищенні граничного значення кількості помилок 280. Лінійне зростання кількості помилок, при збільшенні температури від $70{ }^{\circ} \mathrm{C}$ до $90{ }^{\circ} \mathrm{C}$ під час випробувань дає можливість екстраполювати кількість помилок і прогнозувати кількість помилок при номінальних кімнатних температурах.

Приклад визначення на основі стандарту ISO 18927 терміну зберігання оптичних носіїв за результатами прискорених випробувань наведено на рис. 5. За результатами випробувань, прогнозована тривалість життя архівних цифрових оптичних носіїв Rimage DVD та Blu-ray дисків складає більше 50-ти років [32]. Крім того, визначений термін зберігання CD-R Rimage 52X склав більш ніж 100 років. 


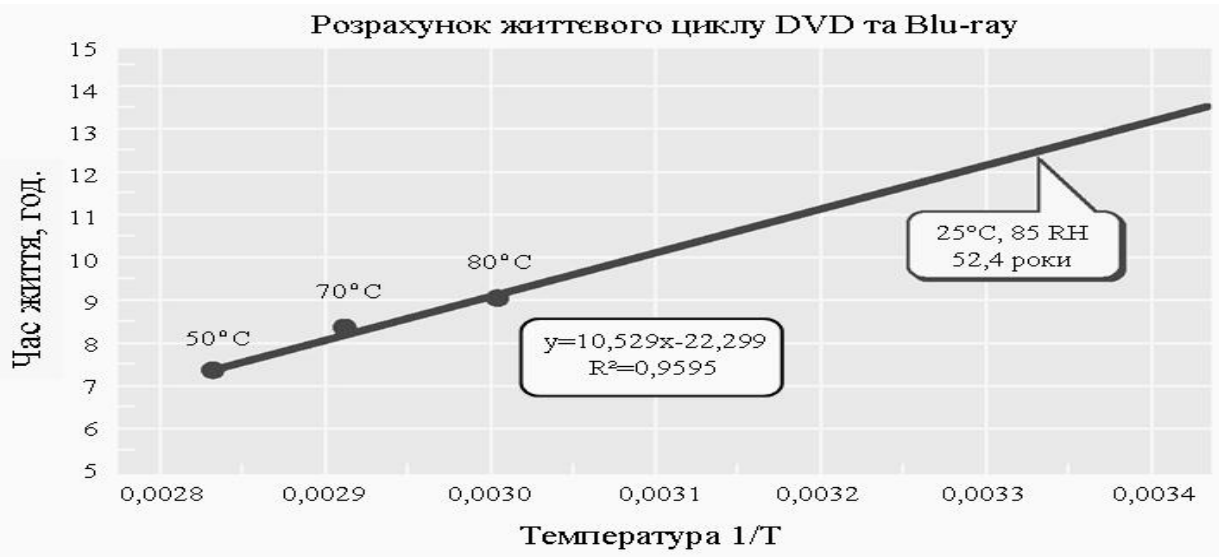

Рис. 5. Прогнозована тривалість життя архівних цифрових оптичних носіїв Rimage DVD та Blu-ray [32]

\section{Технології прискорених випробувань оптичних Аисків Аовготермінового зберігання Ааних}

Значно складніші завдання необхідно вирішувати при створенні методик прискорених випробувань оптичних дисків довготермінового зберігання даних, 3 терміном зберігання даних сотні й тисячі років. Для визначення термінів зберігання даних на М-дисках, які представляють зовсім новий тип оптичних носіїв для довготермінового зберігання даних, використовувався стандарт ISO/IEK 10995. Проведені за цим стандартом випробування носія M-DVD показали очікуваний середній строк служби 1332 роки. Прогнозований термін служби цих дисків може становити як мінімум кілька сотень років. М-диски можуть бути записані та зчитані з використанням стандартного DVD- або BD-пристрою запису-зчитування, що робить їх придатними для зберігання архівної інформації $[7,29]$. На рис. 6 наведені дані про зміну кількості помилок у процесі прискорених випробувань Мдисків [7].

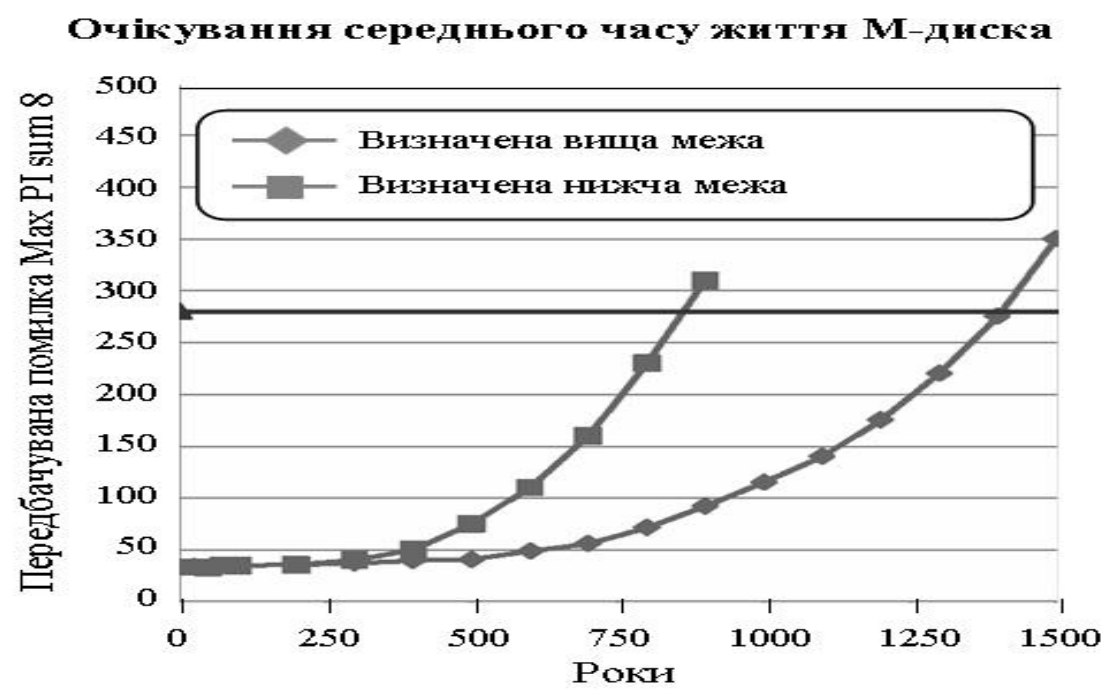

Рис. 6. Результати прискорених випробувань M-DVD носіїв [7] 
Для визначення строків зберігання даних на запропонованих компаніями Sony i Panasonic apхівних дисках AD високої ємності було використано стандарт ISO 16963 (рис. 7).

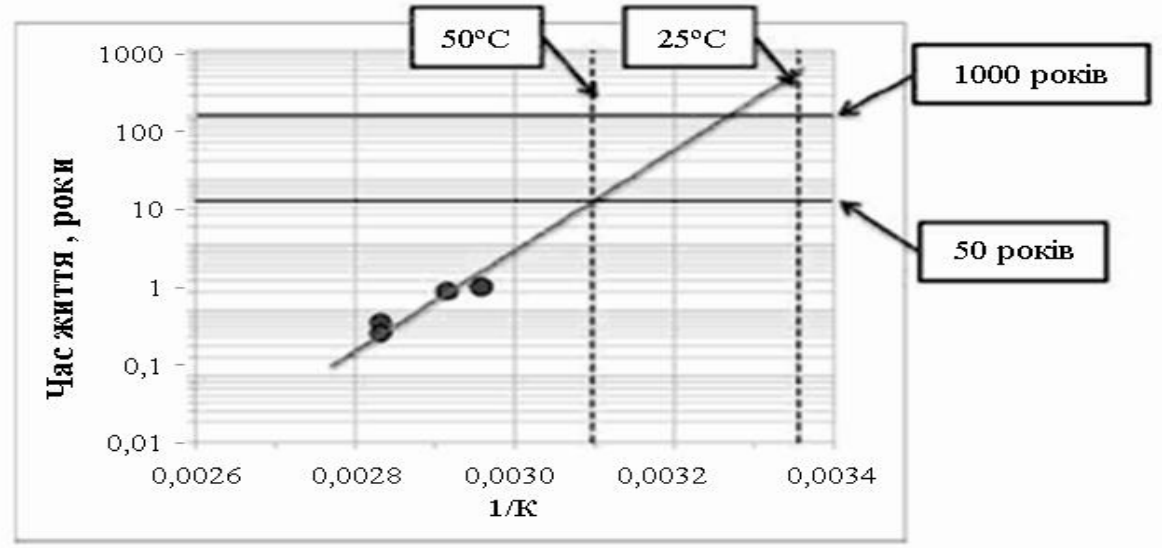

Рис. 7. Результати прискорених випробувань AD-носіїв

На основі рівняння Арреніуса оцінка тривалості життя носія при $50{ }^{\circ} \mathrm{C}$ склала біля 50-ти років та при кімнатній температурі - біля 1000 років.

Для визначення терміну зберігання даних на оптичних носіях довготермінового зберігання даних прискорені випробування проводять при більш високих температурах порівняно з випробуваннями компакт-дисків різних типів. Прискорені випробування багатошарового кварцового носія проводилися при температурах 900-1100 ${ }^{\circ} \mathrm{C}$. Вважається, що можлива втрата записаної інформації на такому носії пов'язана з розпадом нанорешіток, що утворені в процесі запису в кристалі кварцу. Розрахований час розпаду нанорешіток, i, отже, термін служби носія зберігання даних, становить близько $3 \times 10^{20}$ років при кімнатній температурі, що вказує на високу стабільність носія. Термін зменшується при підвищених температурах, але навіть при температурі $462 \mathrm{~K}\left(189^{\circ} \mathrm{C}, 372{ }^{\circ} \mathrm{F}\right)$, час розпаду становить 13,8 мільярда років (рис. 8) [37].

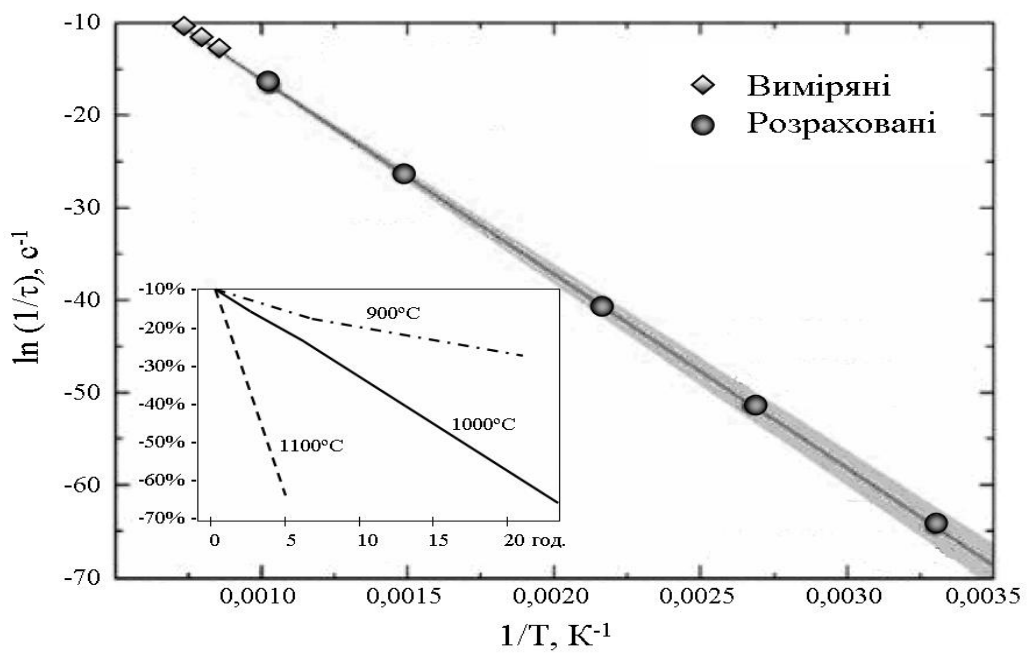

Рис. 8. Результати прискорених випробувань багатошарового кварцового носія інформації 
У Національній метрологічній лабораторії Франції був проведений порівняльний аналіз скляних оптичних дисків довготривалого зберігання зі стандартними компакт-дисками з визначення строків життя оптичних дисків. Результати аналізу наведено на рис. 9 [30].

\begin{tabular}{|l|c|c|c|c|c|c|c|c|}
\hline $\begin{array}{l}\text { Cередній час, } \\
\text { год. }\end{array}$ & 125 & 250 & 375 & 500 & 625 & 750 & 875 & 1000 \\
\hline DVD-ROM & \multicolumn{1}{|l|}{} \\
\hline DVD-R & \\
\hline Скляний диск & \multicolumn{1}{|l}{} \\
\hline
\end{tabular}

Рис. 9. Строки зберігання даних на оптичних носіях різних типів

Випробування, які проводились при температурі $90{ }^{\circ} \mathrm{C}$ і відносній вологості 85 \% показали, що скляні оптичні носії мають термін зберігання значно більший ніж у стандартних компакт-дисків [30].

\section{Висновки}

1. Дані випробувань, проведених з використанням різних способів штучного старіння носіїв, показують, що при нормальних умовах зберігання і дотриманні правил експлуатації компакт-диски зберігають записану інформацію протягом як мінімум кількох десятиліть. На строки зберігання даних на оптичних носіях суттєвий вплив мають технологічні режими виготовлення та використання носіїв.

2. Оптичні носії типу ROM порівняно з іншими типами оптичних носіїв архівного зберігання даних забезпечують значно більший термін зберігання записаної інформації, особливо у випадках виготовлення підкладок таких носіїв з високостабільних матеріалів.

3. Для визначення строків зберігання даних на оптичних носіях довготермінового зберігання інформації можуть використовуватися методи прискорених випробувань відпрацьовані при проведенні випробувань компакт-дисків різних типів.

1. Hedstrom M. Digital preservation: a time bomb for Digital Libraries [Електронний ресурс] / M. Hedstrom. — Режим доступу: https://pdfs.semanticscholar.org/1f78/ff102bc627e675a8df7db2d996 c69faad8cd.pdf. - Назва з екрану.

2. Wan S. Optical storage: an emerging option in long-term digital preservation / S. Wan, Q. Cao, C. Xie // Front. Optoelectron. — 2014. - Vol. 7, N 4. — P. 486-492.

3. Колесов A. Gartner о положении дел на рынке архивирования корпоративной информации [Електронний ресурс] / А. Колесов. - Режим доступу: www.pcweek.ru/ecm/article/detail.php?ID= 169298. - Назва з екрану.

4. Устинов В. Хранение данных на CD- и DVD-дисках: на наш век хватит? [Електронний pecypc] / В. Устинов. — Режим доступу: http:/yugcontract.ua/news/articles/34965.html. — Назва 3 екрану.

5. Шаплбаров И. Перевод архивов в электронный вид - актуальная, но пока неразрешимая задача / Ігор Шаплбаров // PC WEEK/RE. — 2015. — № 6. - C. 3-4. 
6. Металеві носії для довготермінового зберігання інформації / [Петров В.В., Крючин А.А., Шанойло С.М. та ін.]; відповід. ред. О.Г. Додонов. - НАН України, Ін-т проблем реєстрації інформації. - К.: Наук. думка, 2005. -132 с.

7. Permanent Digital Data Storage: A Materials Approach / B.M. Lunt, R. Davis, D. Hansen [et al.] // [Електронний ресурс]. - Режим доступу: http://purl.pt/24107/1/iPres2013_PDF/Permanent\% 20Digital\%20Data\%20Storage\%20A\%20Materials\%20Approach.pdf. - Назва з екрану.

8. Digital Content Creation [Електронний pecypc]. - Режим доступу: nhttp://www.library. illinois.edu/dcc/. - Назва з екрану.

9. Bradley K. Risks Associated with the Use of Recordable CDs and DVDs as Reliable Storage Media in Archival Collections - Strategies and Alternatives National Library of Australia, Canberra [Електронний ресурс]. — Режим доступу: www.unesco.org/webworld/risk/. — Назва з екрану.

10. «Archival Disc» standard formulated for professional-use next-generation optical discs [Електронний ресурс]. — Режим доступу: http://www.sony.net/SonyInfo/News/Press/201403/140310Е/. - Назва з екрану.

11. Оптические диски для долговременного хранения информации / В.В. Петров, В.М. Пузиков, А.А. Крючин [и др.] // Наносистеми, наноматеріали, нанотехнології. — 2009. — Т. 7, № 3. - C. $825-832$.

12. Method of aberration compensation in sapphire optical disks for the long term data storage / V.V. Petrov, V.P. Semynozhenko, V.M. Puzikov [et al.] // Functional Materials. — 2014. — Vol. 21, N 1. - P. 105-111.

13. Fahrenheit 2451 - Preserve Your Data in a Sapphire Disk: Preserve your most precious memories for thousands of years [Електронний ресурс]. - Режим доступу: http://icrowdnewswire.com/ 2015/06/30/fahrenheit-2451-preserve-your-data-in-a-sapphire-disk-preserve-your-most-precious-memoriesfor-thousands-of-years-the-only-storage-medium-that-resists-fire-water-and-time/. - Назва з екрану.

14. Towards Gigayear Storage Using a Silicon-Nitride/Tungsten Based Medium [Електронний pecypc] / Jeroen de Vries, D. Schellenberg, L. Abelmann [et al.] — Режим доступу: arXiv:1310.2961 — Назва з екрану.

15. Оптичні носії для довготермінового зберігання інформації / В.В. Петров, А.А. Крючин, С.М. Шанойло [та ін.] // Страховий фонд документації. — 2016. — № 1. - C. 44-55.

16. Shahani C.J. Longevity of CD Media Research at the Library of Congress [Електронний peсурс] / C.J. Shahani, B. Manns, M. Youket. - Режим доступу: https://www.loc.gov/preservation/ resources/rt/studyofCDlongevity.pdf. — Назва з екрану.

17. NIST/Library of Congress (LC), Optical Disc Longevity Study [Електронний ресурс]. — Peжим доступу: https://www.loc.gov/preservation/resources/rt/NIST_LC_OpticalDiscLongevity.pdf. Назва з екрану.

18. Lunt B.M. How Long Is Long-Term Data Storage? Archiving 2011 Final Program and Proceedings [Електронний ресурс]. — Режим доступу: http://www.imaging.org/site/PDFS/Reporter/ Articles/REP26_3_4_ARCH2011_Lunt.pdf. — Назва з екрану.

19. Березін Б.О. Протидія деструктивним впливам при архівному зберіганні інформаційних об’єктів на оптичних носіях / Б.О. Березін, С.І. Примушко // Реєстрація, зберігання і оброб. даних. - 2015. - 17, № 4. - C. 49-58.

20. Navale $V$. Predicting the Life Expectancy of Modern Tape and Optical Media / V. Navale // RLGDigiNews. - 2005, Aug 15. - 9:4.

21. Permanence, care, and handling of CDs including CD-ROM, Writable CD, and Kodak Photo CD [Електронний ресурс]. — Режим доступу: http://www.unesco.org/webworld/ramp/html/r9704e/ r9704e12.htm. - Назва з екрану. 
22. Shahani C.J. An investigation of the estimated service life of prerecorded compact discs (CDROM) [Електронний ресурс] / C.J. Shahani, M.H. Youket, N. Weberg. — Режим доступу: https://www.loc.gov/preservation/resources/rt/CDservicelife_rev.pdf. - Назва з екрану.

23. Naicker $R$. Optical media is set to become the new data archival standard [Електронний peсурc] / R. Naicker. - Режим доступу: http://accountingweekly.com/optical-media-is-set-to-become-thenew-data-archival-standard/. - Назва з екрану.

24. Characterization of the plastic substrates, the reflective layers, the adhesives, and the grooves of today's archival-grade recordable DVDs / G. Jiang , F. Rivera, Supriya Singh Kanyal [et al.] // Opt. Eng. - 2011. - Vol. 50, N 1. - 015201.

25. Materials for Optical Disc / F.-K. Bruder, K. Douzinas, U. Franz [et al.] // Substrates MRS Bulletin. - 2006. - Vol 31, Is. 04. - P. 299-307.

26. Understanding CD-R and CD-RW disc longevity [Електронний ресурс]. — Режим доступу: www.osta.org/technology/cdqa13.html. - Назва з екрану.

27. Evaluation of Data Stability and Analysis of Degradation Factors of Digital Versatile Disk Recordable (DVD+R) for Archival Application / Kwan-Yong Lee, Dong-Soo Lim, Ki-Hyun Kim [et al.] // Japanese Journal of Applied Physics. — 2012. — Vol. 51, N 8. — 08JC01.

28. Archival Grade Gold Discs for Archiving Digital Storage — Archival DVD Media Verbatim.mht [Електронний ресурс]. - Режим доступу: G:\Архивное хранение\Blank DVD-R Назва з екрану.

29. Summary Report by ISO/IEC 10995 Test Program Performed by Millenniata on M-DISC ${ }^{\mathrm{TM}}$ DVD [Електронний ресурс]. — Режим доступу: http://www.mdisc.com/uploads/M-DISC_1sheet_Test _Summary.pdf. — Назва з екрану.

30. Syylex permanent storage. Longevity tests [Електронний ресурс]. - Режим доступу: http://www.syylex.com/longevity_tests.html. — Назва з екрану.

31. $C D-R$ and DVD-R RW Longevity Research [Електронний ресурс]. - Режим доступу: https://www.loc.gov/preservation/scientists/projects/cd-r_dvd-r_rw_longevity.html. — Назва з екрану.

32. Rimage Media-CD/DVD/BD Specifications [Електронний pecypc]. - Режим доступу: http://www.rimage.com/images/stories/ProductBriefs/CD-DVD-BDSpecs.pdf. — Назва з екрану.

33. Development of a Testing Methodology to Predict Optical Disk Life Expectancy Values [Електронний ресурс]. - Режим доступу: http://cool.conservationus.org/byorg/nara/nistsum.html. — Назва з екрану.

34. Podio F.L. Development of a Testing Methodology to Predict Optical Disk Life Expectancy Values NIST Special Publication 500-200 Summary Prepared byTechnology Research Staff National Archives and Records [Електронний ресурс] / F.L. Podio. - Режим доступу: http://nvlpubs.nist.gov/ nistpubs/Legacy/SP/nistspecialpublication500-200.pdf. - Назва з екрану.

35. Irie M. Standardized Life Expectancy of High-Speed Recordable Optical Disks / M. Irie, Y. Okino // IEEE Transactions on Magnetics. — 2007. - Vol. 43, N 2. - P. 864-866.

36. Iraci J. The Relative Stabilities of Optical Disc Formats / J. Iraci // Restaurator. — 2005. Vol. 26, N 2. - P. 134-150.

37. Seemingly Unlimited Lifetime Data Storage in Nanostructured Glass / J. Zhang, M. Gecevicius, M. Beresna, P.G. Kazansky // Phys. Rev. Lett. — 2014. — Vol. 112. — 033901. 